DORIT URD FEDDERSEN-PETERSEN

\title{
Vocalization of European wolves (Canis lupus lupus L.) and various dog breeds (Canis lupus f. fam.)
}

\author{
Dedicated to Professor Dr. Dr. H. H. Sambraus on the occasion of his $65^{\text {th }}$ birthday
}

\begin{abstract}
Summary
Barking in domestic dogs still remains a topic of controversial discussions. While some authors assess dogbarking an acoustic means of expression becoming more and more sophisticated during domestication, others name this sound type "non-communicative". Vocal repertoires as works on individual sound types are rare, however, and there has been almost no work done on low-intensity, close-range vocalizations, yet such types of vocalization are especially important with the more social canids, hence, with the human-dog-communication and understanding of dogs. Most of the investigations published so far are based on auditive sound impressions and lack objectivity. The principal method used in this study was sonagraphic. This facilitates the identification of sounds and reveales, whether subjective classification can be verified by objectively measured parameters. Finally, meanings, functions and emotions were examined for all the major sounds described and are discussed in terms of relationships between sound structure and signal function, signal emission and social context as behavioural response, and overlapping channels of communication. Ontogeny of acoustic communication in 11 European wolves has been compared to various dog breeds ( 8 Standard Poodles, 8 Toy Poodles, 15 Kleine Münsterländer, 11 Weimaraner Hunting Dogs, 16 Tervueren, 12 American Staffordshire Terriers, and 13 German Shepherds, 12 Alaskan Malamutes, and 9 Bull Terriers) from birth up to 8 (12) weeks resp. 4 (12) months of age. Noisy and harmonic sound groups were analysed separately as overriding units. Following parameters were used: $f \max =$ maximum of spectrographic pictured sounds $(\mathrm{Hz}), \mathrm{xfo}=$ mean of the lowest frequency band of harmonic sounds $(\mathrm{Hz}), x \mathrm{fd}=$ mean of the frequency of strongest amplitude of noisy sounds $(\mathrm{Hz})$, delta $\mathrm{f}=$ frequency range of sounds $(\mathrm{Hz})$, duration of sounds (ms). Statistical analysis was run on "Statistica", Release 4,0. Within the sound type barking 2 to 12 subunits were classified in the different breeds, according to their context-specific spectrographic design, and behavioural responses. Categories of function / emotion include f.e. social play, play soliticing, exploration, caregiving, social contact and "greeting", loneliness, and agonistc behaviours. "Interaction" was the most common category of social context for masted barkings ( $56 \%$ of occurences). Especially close-range vocalizations, concerning the major sound type of most domestic dogs, the bark, evolved highly variable. However, the ecological niche of domestic dogs is highly variable, just as the individual differences in the dogs are, which seem to be breed-typical to a great extent. Thus, complexity within the dog's vocal repertoire, and therefore enhancement of its communicative value, is achieved by many subunits of bark, some standing for specific motivations, informations and expressions. Complexity within the dogs'vocal repertoire is extended by the use of mixed sounds in the barking context. Transitions and gradations to a great extend occur via bark sounds: harmonic, intermediate and noisy subunits.
\end{abstract}

Key Words: vocalization, functions of barking, interaction, communication, domestication, selection.

\section{Zusammenfassung}

Titel der Arbeit: Lautăußerungen beim Wolf und verschiedenen Hunderassen

Über die Funktion des Bellens bei Hunden wird sehr kontrovers diskutiert. Während einige Autoren dem Lautsystem Bellen eine kommunikative Bedeutung zumessen, die im Laufe der Domestikation fortschreitend subtiler und differenzierter wurde, bezeichnen andere das Bellen als „nicht-kommunikativ“. Über hundliche Lautäusserungen ist bislang wenig gearbeitet worden, dieses bezieht sich insbesondere auf Lautanalysen im Nahbereich. Die Mehrzahl der bislang publizierten Untersuchungen basiert auf der Beschreibung von Lauteindrlicken und ist wenig objektiv. Vorliegende Untersuchungen basieren auf sonagraphischen Analysen hundlicher Lautăusserungen. Diese Methodik erleichtert die Identifikation von Lauten und Uberpraft, ob die subjektive Einteilung von 
Lauten verifiziert werden kann durch objektivierbare physikalische Parameter. Schließlich wurden die Funktionen, Emotionen und Intentionen furr die hăufigsten Laute beschrieben und in ihrer Beziehung zwischen Lautstruktur und und Signalbedeutung, Signalabgabe wie entspreciendem sozialen Kontext und der jeweiligen Antwort analysiert. Die Ontogenese der akustischen Kommunikation von 11 Europăischen Wolfen wurde verglichen mit der entsprechenden Entwicklung verschiedener Hunderassen ( 8 Großpudel, 8 Zwergpudel, 15 Kleine Münsterländer, 11 Weimaraner, 16 Tervueren, 12 American Staffordshire Terrier, 13 Deutsche Schaferhunde, 12 Alaskan Malamutes und 9 Bull Terrier), vom Zeitpunkt der Geburt bis zum Alter von 8 (12) Wochen bzw. 4 (12) Monaten. Parametererfassung: Für die Lautanalyse wurden folgende Parameter gewăhlt: 1. tonale (harmonische, klanghafte) und atonale (geräuschhafte) Strukturauspragungen als ubergeordnete Einheiten. 2. Hinzu kamen die Grundfrequenz (fo), das niedrigste Frequenzband harmonischer Laute, der Maximalwert der tonalen und atonalen Laute (fmax), das arithmetische Mittel xfo bzw. xfd (Hz) sowie die Standardabweichungen fúr jeden Laut sowie die Differenz von fomin und fomax (bzw. fdmin und fdmax fur atonale Laute) als Delta fo bzw. Delta fd. Die Lautdauer wurde in $t(\mathrm{~s})$ ermittelt. Die statistische Analyse erfolgte mittels "Statistica", Release 4,0. Innerhalb der Lautgruppe "Bellen" konnten für die verschiedenen Rassen 2 bis 12 Untergruppen 2 klassifiziert werden, nach dem kontext-spezifischen sonagraphischen Design sowie den Reaktionen des Empfängers. Die Kategorien schlossen z.B. Sozialspiel, Spielaufforderung, exploratives Verhalten, Fürsorgeverhalten, soziale Begrüung, soziale Kontaktaufnahme, Isolation, und agonistische Situationen ein. Am hăufigsten wurde im Zuge einer Interaktion gebellt ( $56 \%$ aller Verhaltensweisen mit Bellen). Insbesondere im Nahfeld wurde ausgesprochen differenziert uber das Bellen kommuniziert. Bellen erwies sich als sehr variabel in Struktur und situativem Kontext, passend zur variablen okologischen Nische des Hausstandes. Rassetypische Besonderheiten im Bellverhalten werden herausgestellt. Die Komplexität innerhalb der vokalen Kommunikation unter Hunden erfolgt zu einem Großteil uber die zahlreichen Belluntergruppen, von denen einige fur ganz spezielle Motivationenen, Informationsubermittlungen und Ausdrücke stehen. Die Komplexităt innerhalb des "Bellsystems" wird durch Mischlaute und Übergănge noch erhöht. Es gibt harmonische und gerăuschhafte Bellformen sowie Übergänge. Wölfe bellen ausschließlich geräuschhaft. Schlüsselwörter: Vokalisation bei Haushunden, Bedeutung des Bellens, Kommunikation, Domestikation, Zucht-

\section{Introduction}

Closely related canids, such as domestic dogs of various breeds and their progenitor, the wolf (Canis lupus L.), exhibit under comparable living conditions, alongside conspicuous similarities, a number of dissimilarities in social behaviour, concerning especially social communication - with marked intraspecific variability (FEDDERSEN-PETERSEN, 1991).

As such, comparative study of wolves and dogs offer excellent opportunities to record constants in regard to the development and significance of particularities in individual or species-typical expressive behaviour - as well as those induced by domestication and selective breeding.

Little seems to be known of "man's best friend" and its particular kind of relationship with man.

This is also true for the relationship between experimenter and dog: dogs can be very sensitive to the signals we give off, to a person's "body language", while human ability to interpret signals is, at best, mixed. Wolves and dogs form working relationships with man - we have to consider those sorts of question in future (DAVIS and BALFOUR, 1992).

Additional, there still exists a deficiency of quantitative data which is more than counterbalanced by an excess of unproven speculations. The dog is a special kind of domestic animal, living mostly in close association with man, many breeds or populations are intimate social partners to man since thousands of years, some breeds even preferring man to conspecifics (FEDDERSEN-PETERSEN, 1996 a). Specific or domestication-induced variations in expressive behaviour correspond to the phylo- 
genetic (evolutionary) or domestication-induced differences in the social organization and the possibilities of social adaptation.

Preliminary examinations on "Normal behaviour" in domestic dogs which stimulated an investigation on vocalization in wolves and various dog breeds

"Normal behaviour" of domestic animals usually is defined as behaviour of healthy animals living in a reference system of "semi-natural" environment.

Behavioural studies carried out under "semi-natural" housing conditions, with dogs living in packs, in comparison to a wolf pack of the most equavalent number of members, sex ratio and age, demonstrated the inability of some breeds (poodles, retrievers, pugs f.e.) to cooperate and compete, as in establishing and maintaining a rank order (FEDDERSEN-PETERSEN, 1996 a). Interactions were not adaptive, and the members could not cope with challenges from the environment. They did not succeed in removing a threat, the situation became uncontrollable and the state stress remained. Acute stress became chronic.

Others (German Shepherds, Alaskan Malamutes f.e.) did not leave the health issue or what it is, this means that if an individual evaluates an event or state in the environment as a threat (i.e.a stressor) and the animal is able to reduce or eliminate that threat by taking some behavioural action, then the situation is controllable. They were mentally in quite better shape, living under "semi-natural" conditions.

The groups differed significantly with respect to 5 of 7 behavioural measures:

1. much more frequent and much more severe aggressive behaviour in poodles and retrievers, much more often escalations of aggressive communications;

2. much more frequent and variable social play in the wolves, German Shepherds and Alaskan Malamutes, showing aggressive encounters in a more ritualized manner;

3. greater social tolerance in the wolves, German Shepherds and Malamutes;

4. more nonagonistic approaches in them - and

5.more allogrooming.

Many dog breeds are outside the bounds of possibility to communicate approximately precisely on account of an "extreme diversity in morphological characters" (HERRE and RÖHRS, 1990).

In many breeds there are just fragments in the mimic area in comparison to the wolfish diversity, the fine details, and gradations. In brachycephalic breeds f.e., the forehead always is wrinkled, the nose area too, and teeth baring often is not possible because of prominent flews.

Thus, several facial regions and a lot of signals got lost for communication. The channel of acoustic communication seems to be partly hypertrophic in many breeds, especially different barking forms occur in very differing social situations. Living in packs, however, barking as a whole seemed to cause excitements, above all, by allomimetic behaviour, was a kind of handicap for problem solving in social live. Barking produces the impression to be directed to man, respectively to living circumstances with man. In wolves, the meanings and functions of barking are less varied, as we know by now, and especially include the following: warning, defense and protest (SCHASSBURGER, 1993). 


\section{Hypotheses on meanings and functions of barking in domestic dogs}

Vocalization, especially barking of domestic dogs, still remains a topic of controversial discussions. While some authors assess dog-barking an acoustic means of expression, becoming more and more sophisticated during domestication (ZIMEN, 1971; FEDDERSEN, 1978, and f.e. FOX, 1978) others name this sound type "noncommunicative" (COPPINGER and FEINSTEIN, 1990), or they ascertain no context specific structuremarks in bark sounds and call them "generell - excitement - sounds" (BLEICHER, 1963; ALTHAUS, 1982; TEMBROCK, 1976).

Vocal repertoires as works on individual sound types are rare, however, and there has been almost no work done on low-intensity, close-range vocalizations, yet such types of vocalization are especially important with the more social canids (SCHASSBURGER, 1993), hence, with the human - dog-communication and understanding of dogs.

Most of the investigations of this subject published so far are based on auditive sound impressions and lack objectivity.

This study presents a model for future vocalization studies in domestic dogs (Canis lupus $\mathrm{f}$. familiaris), a model which draws parallels between structure, motivation, emotion, and ontogeny to arrive at a more comprehensive understanding of sound systems in various dog breeds.

\section{Material and Method}

The principal method used in this study was sonagraphic. This facilitates the identification of sounds and reveales, whether subjective classification can be verified by objectively measured parameters.

Finally, meanings, functions and emotions were examined for all the major sounds described and are discussed in terms of relationships between sound structure and signal function, signal emission and social context as behavioural response, and overlapping channels of communication.

\section{Animals}

Ontogeny of acoustic communication in 11 European Wolves (Canis l. lupus L.) (cubs from two litters, located in the Zoological Garden, Institut fur Haustierkunde) has been compared to various dog breeds (8 Standard Poodles, 8 Toy Poodles, 15 Kleine Münsterländer, 11 Weimaraner Hunting Dogs, 16 Tervueren, 12 American Staffordshire Terriers, 13 German Shepherds, 12 Alaskan Malmutes, and 9 Bull Terriers) from birth up to 8 (12) weeks resp. 4 (12) months of age. The dogs were kept in open-air enclosures (poodles, Alaskan Malamutes) or/and housed in companionship with their breeders.

\section{Meanings, functions, and emotions of sounds}

Determination of the ontogeny of sounds was made on the basis of both auditive judgement and subsequent to initial sonagram analysis. Auditive sound classification was proved by the Interobserver Reliability Test (LEHNER, 1979) which in case of the Toy Poodles corresponded with sonagram analysis about $98 \%$.

Moreover, the determination of meanings, functions, and emotions of sounds produced 
in particular stages of development, was made on the basis of social contexts in which sounds were tape recorded. Recording followed 'focal sampling' (MARTIN and BATESON, 1986) up to 4 weeks of age.

The following parameters were used in a discriminant analysis:

- harmonic and noisy sounds were taken as overriding units,

- $\mathrm{fmax}=$ maximum of spectrographic pictured sound $(\mathrm{Hz})$,

- $x f o=$ mean of the lowest frequency band of harmonic sounds,

- $\mathrm{xfd}=$ mean of the frequency of strongest amplitude of noisy sounds,

- delta $\mathrm{f}=$ frequency range of sounds $(\mathrm{Hz})$,

- duration of sounds (ms).

\section{Statistical analysis}

Discriminant analysis was used to control the auditive classification of sounds.

Noisy and harmonic sound groups were analysed separately.

The statistical analysis was run on "Statistica", Release 4,0 (Statsoft 1993).

\section{Results}

According to SCHASSBURGER (1993), the wolf's vocal repertoire consists of 11 basic sound types. In the breeds Alaskan Malamutes, Kleiner Münsterländer, Weimaraner hunting dogs, and Tervueren the vocal repertoires appeared very similar, just as meanings, functions, and emotions, behavioural responses and overlapping channels of communication did. In addition, a lot of more subtile sound types as combinative vocalizations, sudden changeover from one sound to another, and gradual transformations of one sound type into another have been found. Especially in poodles (standard and toy) and American Staffordshire Terriers the vocal repertoires turned out to be reduced and were much more stereotyped in some close-range vocalizations (OHL, 1996; REDLICH, 1998). American Staffordshire Terrier pups, showing marked crude mimics because of their wrinkled face, pronounced flews and lop ears of poor expressiveness, emitted 4 (5) basic sound types only. Sound series of growling were predominant from 3 weeks onwards, combined with teeth baring and nose wrinkled, in situations when social play escalated into agonistic encounters. There are some reference points for positive correlations between expressive reductions in the optic area and a reduced and more stereotyped vocalization.

\section{Results on bark sounds}

But this is not true for the basic sound type barking, in wolves a single, short sound of the noisy type, occuring solely within aggressive contextual categories (threat, attack, warning, defense, and protest).

Within the sound type barking 2 to 12 subunits were classified in the different breeds, according to their context-specific spectrographic design, and behavioural responses.

Infantile bark (pup yelp), a harmonic sound ( $\mathrm{fo}=240-920 \mathrm{~Hz} ; \mathrm{t}=63-306 \mathrm{~ms}$ ), emitted spontaneously, as a distress call, or a kind of protest. Harmonic play bark showing a spectrographic design varying from few wide frequency bands to numerous narrow bands (fo $=160-880 \mathrm{~Hz} ; \mathrm{t}=69-538 \mathrm{~ms}$ ). Mixed sounds involving concurrent 
superimposition of growl or f.e. noisy bark were abundant (Fig.).

Harmonic play bark predominantly was vocalized during relaxed social plays. The nonaggressive context obviously includes metacommunicative functions ("What follows is play", BEKOFF, 1987) on account of the high frequency of initiated social plays.

"Christmas tree" bark shows the "Christmas tree" effect (SCOTT, 1976): the appearance on the sonagram of this sequential loss of overtones is referred to the form of a christmas tree. In poodles noisy overlappings occurred frequently (xfd=696 Hz), whereas "christmas tree" bark in German Shepherds and Alaskan Malamutes, combined with the bow or playful approaches, pawing and sudden runaways, was a pure harmonic sound, often combined with a specific vibrato-growl, probably characterizing the play-situation furthermore. Noisy bark, however, was vocalized in the Malamutes in agonistic contexts only (competition for resources f.e.). Series of these short, modulated play-soliticing barks $(x f d=1206 \mathrm{~Hz})$ often were combined with growls and other bark subunits (Fig., Bull Terrier). Elements of this subgroup exclusively were found as play-soliticing-signals from the 16 th day on. Corresponding mimics and body signals of play accompanied this vocalization in standard poodles, German Shepherds and Weimaraner hunting dogs.

In Bullterriers the optic area of communication was strikingly poor.

Noisy play bark is a harsh, short sound of the noisy type, low pitched with an extremely short, sharp rise ( $x f d=1206 \mathrm{~Hz}$; Bull Terriers) but rounded drop. Sound series and variable, sound combinations were common. The social context is social (solitary) play.

However, noisy play bark characterizes more harsh play-fightings. This sound was predominant in play-fightings of American Staffordshire Terriers and Bull Terriers, often showing change - overs to aggressive interactions.

Finally, threat bark, warning bark were the most low pitched sounds ( $x f d=200$ $2360 \mathrm{~Hz})$ among the noisy bark sounds and the shortest in time ( $\mathrm{t}=50,1 \mathrm{~s})$.

A typical feature for this subgroup were several single sounds vocalized in rapid succession.

\section{Conclusions from structural characteristics of major vocalizations}

Differences are relevant to duration of sounds. Furthermore, bark sounds in wolves are a good deal more low pitched and much less variable in structure and in social context as in the dogs.

Finally, this vocalization indicates striking differences also between the breeds (Table).The different numbers of discrete sounds in the dog breeds, compared to the wolf, seem to be of much more importance. Wolves vocalize noisy barks only, while harmonic forms are totally lacking. This is also true for the growl sounds (Table). A comparison between the breeds elucidates that poodles show least of all subunits of these sounds.

Differences between breeds seem to exist less in structural characteristics of vocalizations (Table) but in number of discrete sounds und its frequency in different contexts.

Further investigations are necessary to shed light on this matter. 


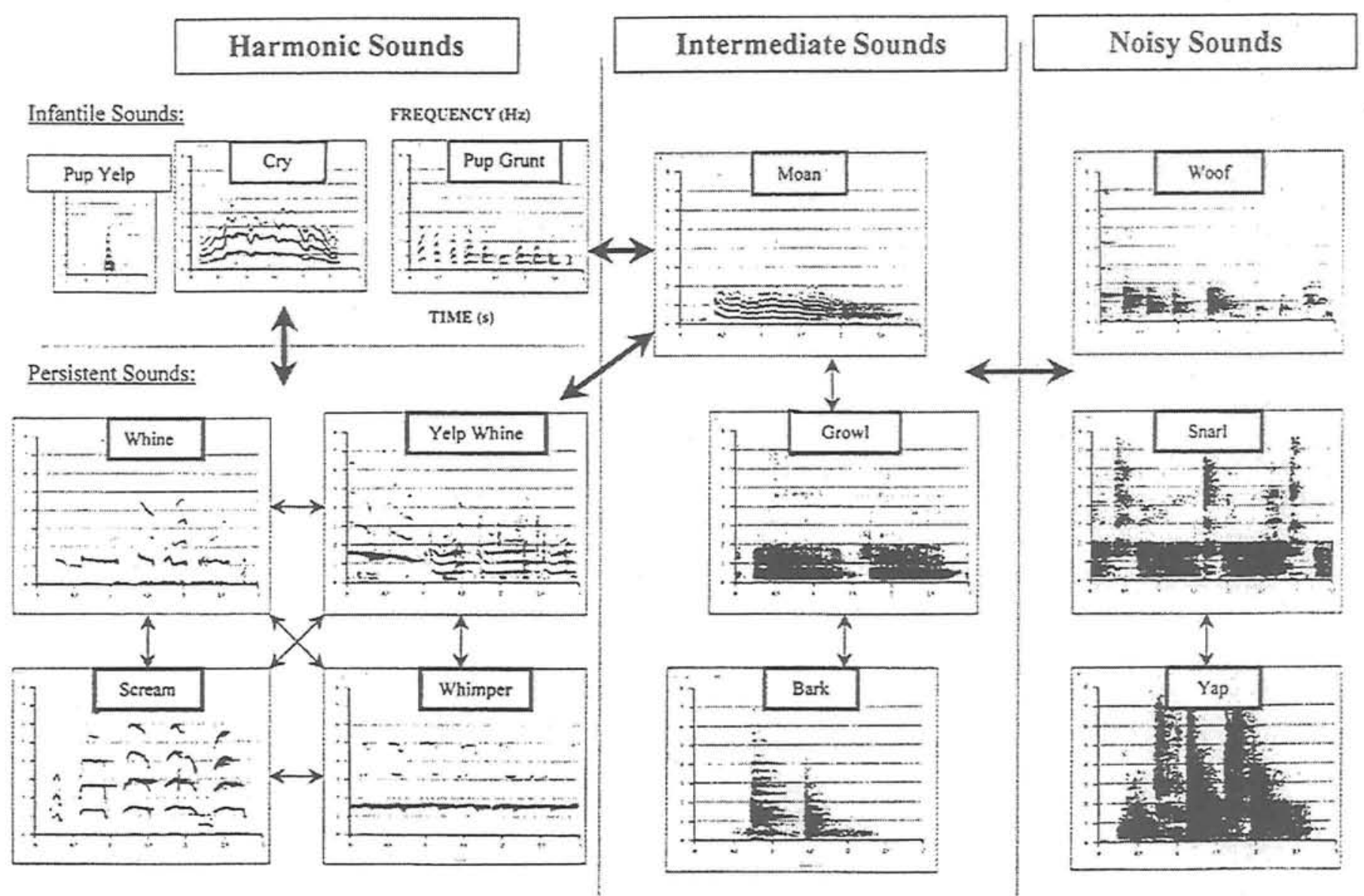

$\longleftrightarrow$ : possible transitions within heterotypical sound sequences

Fig. : Vocal repertoire of the Bull Terrier, showing possible transitions within heterotypical sound sequences (growl-bark f.e.) (Lautrepertoire des Bull Terriers; Lautübergänge, die häufige heterotype Lautfolgen bilden, sind durch Pfeile gekennzeichnet (z.B. Knurr-Bellen)) 
Table

Comparison of structural characteristics of major vocalizations in different dog breeds and the wolf (Vergleichende Darstellung von Lautparametern persistierender Lautgruppen bei verschiedenen Hunderassen und dem Wolf)

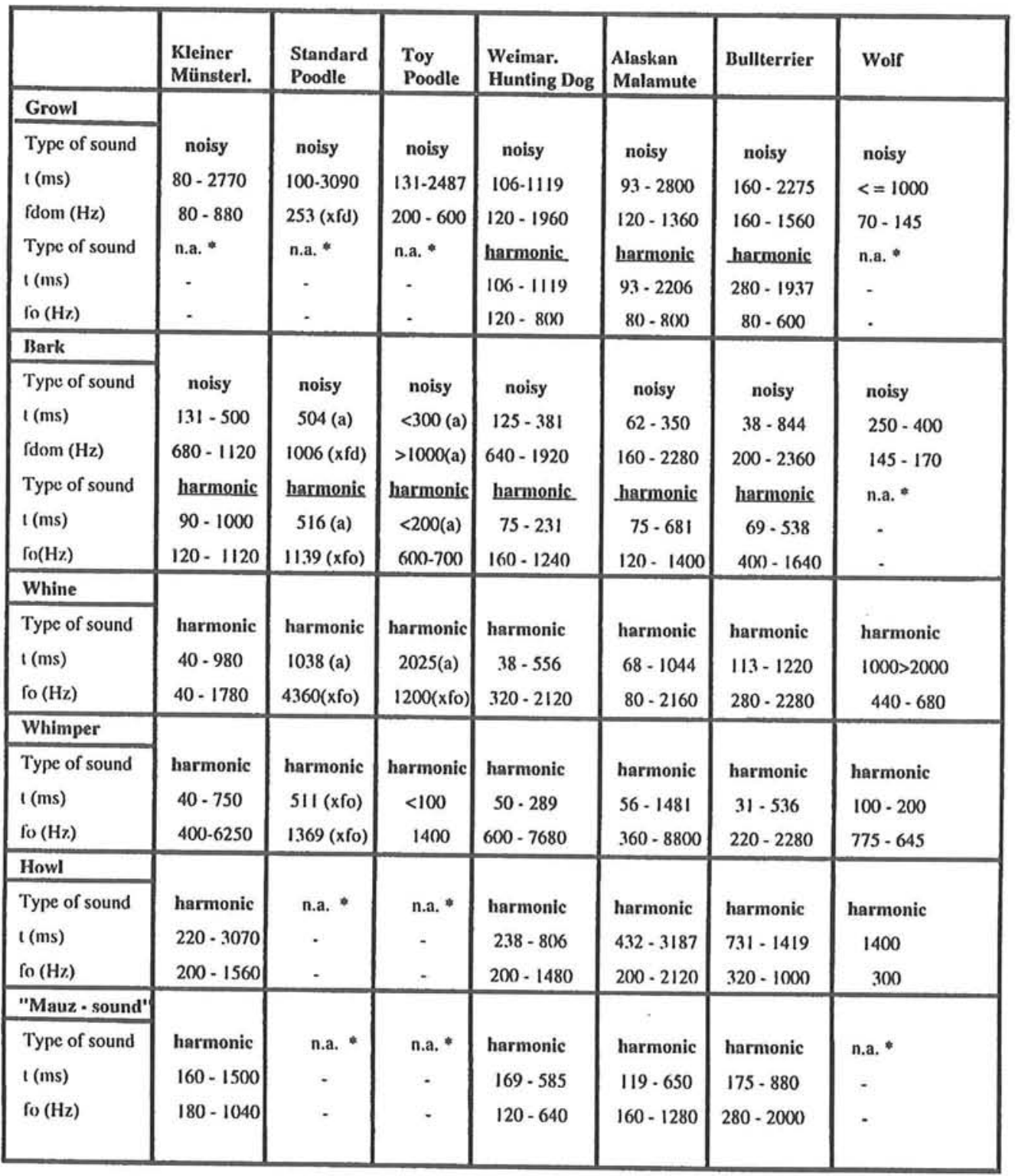

* no analogy: a=average

\section{Discussion}

According to SCHASSBURGER's (1993) idea of the wolf's vocal repertoire, domestic dogs of different breeds neither evolved a stereotyped nor a graded specific sound 
system, both types of vocal repertoire seem to be of adaptive value to dogs'living circumstances with humans. In addition, selective breeding supported special sounds in hunting dogs or other working dogs.

But especially close-range vocalizations, concerning the major sound type of most domestic dogs, the bark, evolved highly variable. However, the ecological niche of "Hausstand" (HERRE and RÖHRS, 1990) is highly variable, just as the individual differences in the dogs are, which seem to be breed-typical to a great extent.

Thus, as a whole, complexity within the dog's vocal repertoire, and therefore enhancement of its communicative value, is achieved by many subunits of bark, some standing for specific motivations, informations and expressions. Complexity within the dogs' vocal repertoire is extended by the use of mixed sounds in the barking context. Transitions and gradations to a great extend occur via bark sounds: harmonic, intermediate and noisy subunits.

\section{Barking as a means of subtile communication}

Categories of function / emotion include f.e. social play, play soliticing, exploration, caregiving, social contact and "greeting", loneliness, and agonistc behaviours (offensive / defensive threat f.e.). "Interaction" was the most common category of social context for masted vocalizations ( $56 \%$ of occurences). Interactions ranged from mildy agonistic biting of infants by adult dogs to affiliate acts like grooming. Additional, there are acoustic signals following or indicating distress via bark sounds or gradations including barks. Parallel to their social life and its quality, the vocalizations of the dogs seem to develop into an increasingly communicative component of social interactions via bark differentiations. The wide-ranging spectrographic structure of the different subunits allows barking to be used meaningful in varying contexts.

These results are inconsistent with COPPINGER and FEINSTEIN's (1990) opinion taking the structural variation of barks as one evidence for the " ... apparent meaninglessness of dog barking". On the contrary, the clearly hypertrophied barking behaviour seems at best qualified for communication of domestic dogs: Many breeds lack visual displays to a great extend, respectively their mimics and gestures are reduced extremely. Thus, the complementary overlap and cooperating of optic and acoustic channels of communications do not fit.

Furthermore, dogs have to communicate with conspecifics and predominant verbalizing humans, thus, qualitative and quantitative changes and shiftings of channels of communication during domestication are quite logic consequences. Almost in wolves, noisy bark sounds occur in many contexts, their meanings are varied and the structure is variable, play barking, however, is lacking. This is also true for the variety of harmonic bark subunits indicating grooming resp. other forms of social contact. During the process of domestication barking probably has been selected and changed highly variable in quality and quantity by breeding. Thus, barking is at best qualified for communication of domestic dogs. 
FEDDERSEN- PETERSEN: Vocalization of European wolves and various dog breeds

\section{References}

ALTHAUS, T.:

Die Welpenentwicklung beim Siberian Husky. Diss. Universitat Bern, 1982

BEKOFF, M.:

Behavioral Development in Terrestrial Carnivores. In: GITTLEMAN, J. (ed.): Carnivore behavior, BLEICHER, N.:

Physical and behavioral analysis of dog vocalization. Am. Journ. Vet. Res. 24 (1963), 415 - 427

COPPINGER, R.; FEINSTEIN, M. :

Hark! Hark! the dogs do bark ... and bark and bark. Smithonian 6 (1990), $119-123$

COPPINGER, R; FEINSTEIN, $M$ :

Why do dogs bark. Smithonian Magazine, 1 (1991), 119 - 129

DAVIS, H.; BALFOUR, D.:

DU'RRE, I:

The inevitable bond. Cambridge University Press, 1992

Untersuchungen zur postnatalen Verhaltensontogenese in den ersten acht Lebenswochen der Jagdhunderasse Weimaraner (Canis lupus f. familiaris). Diplomarbeit, Universităt Hamburg, 1994

FEDDERSEN, D.:

Ausdrucksverhalten und soziale Organisation bei Goldschakalen, Zwergpudeln und deren

Gefangenschaftsbastarden. Diss., Tierärztl. Hochschule Hannover, 1978

ERSEN-PETERSEN, D.: The ontogeny of social play and agonistic behaviour in selected canid species. Bonn. zool. Beitr. 42
(1991), 97-114

FEDDERSEN-PETERSEN, D.:

Zur Ethologie des Haushundes (Canis lupus f. familiaris). Acta Biol. Benrodis, Suppl. 3 (1996a), 7 - 20

FEDDERSEN-PETERSEN, D.:

Ist Bellen furr Hunde kommunikativ? In: Aktuelle Arbeiten zur artgemaßen Tierhaltung 1995. KTBLSchrift 376 (1996), 59 - 71, Darmstadt, 1996b

FEDDERSEN-PETERSEN, D.:

Die kommunikative Bedeutung des "Lautsystems Bellen". Kleintier Konkret Special, 2 - 15. Ferdinand FOX, M.W.: Enke, Stuttgart, 1998

The dog. Its domestication and behavior. Garland STPM Press. New York, London, 1978

GEORGE, E.:

Beitrag zur fruhen Verhaltensontogenese von Bullterriern. Diss., Tierărztliche Hochschule Hannover, 1995

HERRE, W.; ROHRS, M.:

LEHNER, P.N. :

Haustiere - zoologisch gesehen. Gustav Fischer, Stuttgart, 1990

LESCHKE, M.:

Handbook of Ethological Methods. Garland STPM Press, New York, 1979

Die Lautentwicklung bei Schaferhund Welpen. Diss. Humboldt Universităt, Berlin, 1969

MARTIN, P.; BATESON, P.:

OHL, F.: Measuring Behaviour. Cambridge University Press, 1990

Ontogeny of Vocalizations in Domestic Dogs, Breed Standard - Poodle (Canis lupus f. familiaris). Zool.

REDLICH, J.: Beitr. 37 (1996), $199-215$

Verhaltensontogenese von Haushunden (Canis lupus f. familiaris) der Rasse American Staffordshire Terrier. Diss. Tierărztlliche Hochschule Hannover, 1998

SCHASSBURGER, R.M.:

Vocal Communication in the Timber Wolf, Canis lupus, Linnaeus. Structure, Motivation, and Ontogeny. SCOTT, J.P.:

Advances in Ethology 30 (1993). Paul Parey, Berlin and Hamburg

Genetic variation and the evolution of communication. In: Communicative Behavior and Evolution, (HAHN, M.E. and SIMMEL, E.C., eds.). Acad. Press, New York, 39 - 58, 1976

TEMBROCK, G.:

Canid Vocalizations. Behav. Processes 1 (1976), 57 - 75 
Arch. Tierz. $43(2000) 4$

UMLAUF, K.:

Ontogenese der Lautăusserungen bei Jagdhunden der Rasse Kleiner Münsterlănder (Canis lupus f. familiaris). Acta Biologica Benrodis, Suppl. 3 (1996), 31 - 36

ZIMEN, E:

Wrlfe und Königspudel. Piper, 1971

Received: 2000-06-22

Accepted: 2000-07-06

\author{
Author's address \\ Dr. DORIT URD FEDDERSEN-PETERSEN \\ Institut fur Haustierkunde \\ Christian-Albrechts-University \\ Olshausenstr. 40 \\ D - $24118 \mathrm{Kiel}$ \\ Germany
}




\section{Buchbesprechung}

\section{Schafe}

HELMUT KÜHNEMANN

96 Seiten, 58 Farbfotos, 20 Zeichnungen, Ulmer Verlag Stuttgart, 2000, ISBN 3-8001-7480-4, 24,80 DM

Die Haltung von Schafen diente von jeher vorrangig der Erzeugung von Wolle und Fleisch. Wenngleich sich in jüngerer Zeit die Gewichte längst in Richtung Fleisch verschoben haben, gewinnen in der Schafhaltung auch zunehmend Aspekte der Landschaftspflege an Bedeutung. Immer grß̋er wird aber auch der Personenkreis, der Schafe aus Freude am Tier und am lăndlichen Leben hält. Alle diese und andere Haltungsgrunde haben eines gemeinsam. Der Schafhalter muss die Bedurfnisse und Anspruche des Tieres kennen, er muss uber Wissen zur sachgemäßen Haltung, Futterung, Pflege, Gesunderhaltung und Nutzung verfügen. Das Grundwissen zu diesen Fragen will dieses Buch anschaulich vermitteln.

Reich illustriert, informativ und verständlich geschrieben, werden die wichtigsten Voraussetzungen einer sachund tiergemäßen Schafhaltung dargestellt. Nach einfuhrenden allgemeinen Bemerkungen, auch zu Fragen der Schafhaltung oder der richtigen Rassenwahl, enthalt der folgende Abschnitt zur Unterbringung Fragen der Weide- und Stallhaltung. Es folgt der Abschnitt Futterung von der Beschreibung der Futtermittel, uber Futterrationen bis zur praktischen Futterung. Der Abschnitt Nachwuchs informiert uber Fragen der Zucht, Fortpflanzung, Geburt und Aufzucht. Es folgen die Informationen zur Gesundheitsvorsorge, der Krankheitserkennung und -behandlung. Der letzte Abschnitt beschättigt sich mit den Produkten und deren Verwertung.

Den Abschluss des Buches bilden Verzeichnisse, besonders hervorzuheben die wichtigsten Anschriften, die dem Neueinsteiger die Kontaktaufnahme zu Züchtern, Verbänden oder die Schafhaltung tangierende Unternehmen, erleichtern.

In Bild und Wort werden 19 Schafrassen ausgewăhlt und mit ihrer Herkunft, mit ihren speziellen Eigenschaften, Leistungen und ihren besonderen Anspruchen vorgestellt.

Dieses Buch wendet sich an Schafhalter, es ist anwendungsorientiert geschrieben und kann vor allem Personen, die mit der Haltung von Schafen beginnen wollen, durch seine Praxisrelevanz wertvolle Informationen bieten. Darüber hinaus ist dieses Buch wegen seiner Informationen zur sachgemäßen Tierhaltung, vor allem aber wegen seiner sehr schönen Tierfotos, allen Naturfreunden und Tierliebhabern zu empfehlen. 